Crop Breeding and Applied Biotechnology 14: 15-22 2014

Brazilian Society of Plant Breeding. Printed in Brazil

\title{
ARTICLE
}

\section{Evaluation of special grains bean lines for grain yield, cooking time and mineral concentrations}

\author{
Nerinéia Dalfollo Ribeiro ${ }^{1 *}$, Josana de Abreu Rodrigues ${ }^{1}$, Marina Prigol ${ }^{1}$, Cristina Wayne Nogueira ${ }^{1}$, Lindolfo Storck ${ }^{1}$ \\ and Eduardo Muller Gruhn ${ }^{1}$
}

Received 14 March 2013

Accepted 10 November 2013

\begin{abstract}
Genetic variability of 32 inbred special grains bean lines was investigated for grain yield, mass of 100 grains, cooking time, and mineral concentrations in grains, and $\overline{\mathrm{Z}}$ index was used for selection of superior lines in most of the characters. IAC Centauro, IAC Galante, Xamego, Ouro Branco, Montcalm, and Hooter lines presented high yield grain, short cooking time (less than 24 min), and high potassium (>14 $\mathrm{g} \mathrm{kg}^{-1}$ dry matter [DM]), calcium (>1.42 $\left.\mathrm{g} \mathrm{kg}^{-1} \mathrm{DM}\right)$, iron (>97.60 mg kg-1 DM), zinc (>29.05 mg kg-1 $D M)$ and copper $\left(>8.67 \mathrm{mg} \mathrm{kg}^{-1} \mathrm{DM}\right)$ concentrations, and their dietary use is therefore recommended. Cal-96 line presents higher $\bar{Z}$ index for grain yield and for the most of the minerals, and its use is recommended for crosses for the development of superior lines.
\end{abstract}

Key words: Phaseolus vulgaris, nutritional quality, genetic variability, $\overline{\mathrm{Z}}$ index.

\section{INTRODUCTION}

Common bean (Phaseolus vulgaris L.) presents two centers of domestication: the Middle American, with Mesoamericana, Jalisco and Durango races of small grains; and the Andean, with Nueva Granada, Peru and Chile races with medium to large grains (Singh et al. 1991). Beans were gradually dispersed around different countries, and today there is a marked regional preference for grains of different colors, sizes and forms.

In Brazil, $85 \%$ of beans consumed belong to the Mesoamericana race, with carioca tegument (beige with brown streaks) and black color. These grains present mass of 100 grains lower than $25 \mathrm{~g}$; therefore, they are considered small by the classification of Blair et al. (2010). There are no countries importing carioca beans, and its consumption is restricted to the Brazilian market. National black beans production is sometimes insufficient for supplying the domestic market, and they may be imported from Argentina, or from the United States. Since Brazil is the biggest bean producer and consumer worldwide (FAO 2011), a diversification in bean crops would be a determining factor for the culture sustainability.

Beans of white, red, cream and yellow tegument - with coat pattern absent, or striped, or mottled, are well accepted in the international market, but the Brazilian production is quite inexpressive due to the lack of the adapted cultivars with high grain yield. Grains nutritional value varies with the different types of beans. Islam et al. (2002) evaluated the mineral concentration of 1072 bean accessions stored in the Germplasm Bank of the International Center for Tropical Agriculture (CIAT), in Colombia, and evidenced that the germplasm of the Middle American gene pool presented higher calcium, phosphorus, sulphur and zinc concentrations, and lower iron concentration in the grains. Middle American beans accessions of the Institute of Agronomic Sciences of Rwanda also presented high zinc and low iron concentrations in the grains (Blair et al. 2010). However, Talukder et al. (2010), while evaluating bean genotypes grown in Colombia, the United States, Brazil and India observed that Middle American genotypes presented, on average, 16.1\% more zinc and $11.3 \%$ more iron than Andean genotypes.

Beans of different tegument colors of Middle American or Andean origin, known as special grains bean, are more acceptable if, they present faster cooking times and higher grain yield, besides high nutritional value. Grains that in a few minutes of cooking acquire an adequate softness are preferable due to the economy of energy, and to the lower time taken for meals preparation (Rodrigues et al. 2005). Moreover, grain yield must be increased so that cultivation of special grains bean become profitable for rural producers.

\footnotetext{
${ }^{1}$ Universidade Federal de Santa Maria, Departamento de Fitotecnia, 97.105-900, Santa Maria, RS, Brasil. *E-mail: nerineia@hotmail.com
} 
When the selection is performed for many characters simultaneously, the use of selection indexes must be taken into consideration. $\bar{Z}$ index considers the sum of standardized variables for each plot (Mendes et al. 2009). Lines with the highest $\bar{Z}$ index sums are considered promising for selection, since they have presented superiority for most of the desirable characters. The use of $\bar{Z}$ indexes enabled the selection of common bean lines for each particular nutrient, or for the chemical composition as a whole (Silva et al. 2012).

Combined selection for grain yield, mass of 100 grains, and cooking and nutritional quality is a recent standard for special grains bean, and literature in this field is extremely scarce. Therefore, this work aimed at evaluating the genetic variability of special grains bean lines for grain yield, mass of 100 grains, cooking time and mineral concentration, and at using $\bar{Z}$ index for selection of superior lines in the most of characters.

\section{MATERIAL AND METHODS}

Seeds of 32 inbred special grains bean lines $(P h . v u l-$ garis) were obtained from field experiments carried out in two growing season: normal rainy season (with sowing in October 2010), and dry season (with sowing in February 2011). All experiments were carried out in the Bean Breeding Program area at the Plant Science Department of the Federal University of Santa Maria, Brazil. Santa Maria lies in the Central Depression region of Rio Grande do Sul, southern Brazil (lat $29^{\circ} 42^{\prime} \mathrm{S}$, long $53^{\circ} 49^{\prime} \mathrm{W}$ and alt $95 \mathrm{~m}$ asl). Climate is temperate and rainy, with well-distributed rainfall throughout the year, and subtropical temperatures.

A randomized block experimental design was used, with three replications. Treatments consisted of evaluation of 32 inbred special grains bean lines, where 14 of them were of common lines at the two growing seasons (Light Red Kidney, Red Kanner, Ouro Branco, Montcalm, IPR Garça, Chinook, Hooter, BRS Radiante, Cal-96, Branco Graúdo, WAF 75, BRS Executivo, WAF 141 and BRS Embaixador). In the 2011 dry season, another 18 lines were included (IAC Galante, IAC Centauro, Xamego, BRS MG Realce, Rosinha G2, Vermelho Graúdo, Iraí, IAC Harmonia, IAC Jabola, OTG 07-01, Cranberry, OTG $07-$ 09, TB 02-24, OTG 07-03, IAC Boreal, Dark Red Kidney, 38 MON p5-13 and IAC Esperança). In the experiment of 2010 normal rainy season, each plot consisted of four rows $4 \mathrm{~m}$ long, spaced $0.5 \mathrm{~m}$ apart, and the two central lines were used as useable area of $4 \mathrm{~m}^{2}$. In the experiment of 2011 dry season, plots consisted of two rows $4 \mathrm{~m}$ long, spaced $0.5 \mathrm{~m}$ apart, and with a useable area of $4 \mathrm{~m}^{2}$. In this in case, the use of smaller plots was necessary for homogeneity inside the block due to the great number of lines evaluated in the 2011 dry season.
Soil was typical alitic Argisol, Hapludalf, with the following chemical composition in the 2010 normal rainy season: $\mathrm{pH}\left(\mathrm{H}_{2} 0\right)=5.7$; organic matter $=2.0 \%$; phosphorus $=4.5$ $\mathrm{mg} \mathrm{dm}{ }^{-3}$; potassium $=112 \mathrm{mg} \mathrm{dm}^{-3}$; calcium $=6.3 \mathrm{cmol}_{\text {c }}$ $\mathrm{dm}^{-3}$; and magnesium $=2.8 \mathrm{cmol}_{\mathrm{c}} \mathrm{dm}^{-3}$. Soil was prepared in a conventional manner, and fertilization was performed based on the chemical soil analysis. Fertilizer used in sowing furrow was $250 \mathrm{~kg} \mathrm{ha}^{-1}$ of the 5-30-20 formula (nitrogen, phosphorus and potassium). In addition, nitrogen fertilization was split in the growth stage of the first trifoliate leaves (V3), at $20 \mathrm{~kg} \mathrm{ha}^{-1}$ urea (45\% of nitrogen). Micronutrients were not added to the fertilizer.

In the 2011 dry season, the experiment was carried out at the same location of the 2010 normal rainy season. Therefore, fertilization maintenance was carried out, as well as replacement of nutrient export. Fertilizer used in sowing furrow was $190 \mathrm{~kg} \mathrm{ha}^{-1}$ of the 5-30-20 formula, and $20 \mathrm{~kg}$ $\mathrm{ha}^{-1}$ urea was split in the V3 growth stage.

Cultural treatments, and insect and weed control were carried out whenever necessary to rule out competition. Disease control was not carried out.

Plants were harvested and threshed by hand when mature. Agricultural machinery and equipment were not used in the harvesting and processing of grains for avoiding contamination of samples with heavy metals. After manual removal of broken grains and impurities, grains were dried in a drying and sterilization oven with forced air circulation $\left(65-70{ }^{\circ} \mathrm{C}\right)$ until they reached an average moisture content of $13 \%$. Thus, grain yield $\left(\mathrm{kg} \mathrm{ha}^{-1}\right)$ and mass of 100 grains (g) were determined.

Evaluation of cooking time was carried out with 25 grains of each replication. Grains (25) were put in plastic cups of $200 \mathrm{ml}$ and $50 \mathrm{ml}$ distilled water were added. After eight hours of imbibition at room temperature $\left(20 \pm 2{ }^{\circ} \mathrm{C}\right)$, water was eliminated and grains were partially dried with paper towel and placed on the support plate of a Mattson's cooking. The device has 25 pegs of $90 \mathrm{~g}$, and $1.0 \mathrm{~mm}$ of diameter at the tip of the pegs. Each grain was positioned under a peg and the device was placed inside of a domestic pressure pan of 7 liters, filled with 3 liters of boiling distilled water. The pan was kept over heating (with no lid) at medium fire, and when the grain was cooked, peg fell and perforated the grain. The fall average time of the first 13 pegs was registered as the cooking average time of each sample (Ribeiro et al. 2007). For minimizing the environmental effect, the cooking was carried out in air conditioned room $\left(20^{\circ} \mathrm{C}\right)$, in the same position of the stove, at medium fire and in the same pan.

A homogeneous sample of $150 \mathrm{~g}$ of grains per replication was obtained for each line at each growing season. 
For determination of mineral concentrations, $10 \mathrm{~g}$ grain samples from each line were randomly collected from each repetition. Samples were dried in an oven $\left(65\right.$ to $\left.70^{\circ} \mathrm{C}\right)$ until they reached an average moisture content of $13 \%$, and then were weighed. Samples were ground in an analytical knife micromill for producing particles smaller than $1 \mathrm{~mm}$.

Raw beans flour was digested with concentrated nitric acid $\left(\mathrm{HNO}_{3}\right)$, and perchloric acid $\left(\mathrm{HClO}_{4}\right)(1 / 5, \mathrm{v} / \mathrm{v})$ at 60 ${ }^{\circ} \mathrm{C}$ for 12 hours, according to the method described by Ribeiro et al. (2012). The analysis was carried out using an optical emission spectrometer with inductively coupled plasma (ICP-OES) equipped with a Cross Flow nebulizer. The operating conditions of ICP-OES equipment were previously established by Ribeiro et al. (2012), and selected analytical emission lines were automatically determined by the instrument.

Data obtained were submitted to analysis of variance, according to the random block model for grain yield (three replications), and completely randomized design for mass of 100 grains and cooking time (three replications), and mineral concentrations (two replications). Bartlett test (Steel et al. 1997) was applied to check homogeneity of variances of errors found at the two growing season. $F$ test (p-value $<0.05$ ), was used for testing the hypotheses of main effects and interactions of growing season $\mathrm{x}$ line. Effect of lines was considered fixed and the other ones (block, growing season and interaction), random effects. In the joint variance analysis, the interaction was estimated for the common lines at the two growing season, and for the comparison of means, it was used the error mean square and degrees of freedom joint. Comparison of means was carried out using Scott-Knott's test for lines ( $\mathrm{p}$-value $=0.05$ ).

Data of grain yield, mass of 100 grains, cooking time, potassium, calcium, iron, zinc and copper were standardized for parcel, making them directly comparable. Selection index ( $\bar{Z}$ index) was estimated as described by Mendes et al. (2009). However, as the characters were determined using a different number of replications, $\bar{Z}$ index mean was considered for those characters present in $\mathrm{j}$ replication, and the constant with a value of three was added to avoid negative values. Charts were marked to check the contribution given by each standardized character for $\bar{Z}$ index value, facilitating the visual identification among lines with higher $\bar{Z}$ index mean for all characters, using the same procedure described by Mendes et al. (2009). Analyses were carried out with the aid of Microsoft Office Excel spreadsheets, and Genes software (Cruz 2006).

\section{RESULTS AND DISCUSSION}

Variance of experimental error in the two growing seasons was homogeneous ( $p$ value $>0.05$ ), making the analysis of joint variance possible for all evaluated characters. Growing season $\mathrm{x}$ line interaction was significant $(\mathrm{p}$ value $<0.05)$ in relation to grain yield, mass of 100 grains, cooking time and $\bar{Z}$ index (Table 1), characterizing a differentiated effect for special grains bean lines in reaction to the environment variation. For potassium, calcium, iron and copper concentrations, a significant effect was observed for growing

Table 1. Analysis of variance for grain yield (yield, in $\mathrm{kg} \mathrm{ha}^{-1}$ ), mass of 100 grains (mass, $\mathrm{g}$ ), cooking time (cooking, seconds), mineral concentration in grains: potassium ( $\mathrm{g} \mathrm{kg}^{-1}$ of dry matter - DM), calcium ( $\mathrm{g} \mathrm{kg}^{-1}$ of DM), iron ( $\mathrm{mg} \mathrm{kg}^{-1}$ of DM), zinc ( $\mathrm{mg} \mathrm{kg}^{-1}$ of DM) and copper ( $\mathrm{g} \mathrm{kg}$ of DM), and Z index mean for special grains bean lines obtained in normal rainy and dry seasons

\begin{tabular}{|c|c|c|c|c|c|c|c|c|}
\hline \multirow{2}{*}{ Source of variation } & \multirow[b]{2}{*}{ df } & \multicolumn{7}{|c|}{ Mean squares } \\
\hline & & Yield & df & Mass & Cooking & df & Potassium & Calcium \\
\hline Seasons (S) & 1 & $1049296.1^{*}$ & 1 & 1044.8 & $517080.9 *$ & 1 & $157.6^{*}$ & $1.69^{*}$ \\
\hline $\mathrm{SxL}$ & 13 & $465405.9 *$ & 13 & 65.9 & $177490.5^{*}$ & 13 & 9.9 & 0.07 \\
\hline Block/S & 4 & 72440.9 & - & -- & -- & - & -- & -- \\
\hline Error & 88 & 38104.1 & 92 & 6.1 & 15419.8 & 46 & 12.0 & 0.05 \\
\hline \multirow[t]{2}{*}{$\mathrm{CV} \%$} & & 17.53 & & 5.93 & 9.28 & & 22.72 & 16.63 \\
\hline & df & Iron & & Zinc & Copper & & $\overline{\mathrm{Z}}$ index & \\
\hline Seasons (S) & 1 & $1934.9^{*}$ & & 61.3 & $27.8^{*}$ & & 0.7 & \\
\hline Lines (L) & 31 & $1298.1^{*}$ & & $38.5^{*}$ & 4.9 & & $0.52 *$ & \\
\hline SxL & 13 & 641.7 & & 11.1 & 4.8 & & $0.46 *$ & \\
\hline
\end{tabular}

*Significant for the $\mathrm{F}$ test $(\mathrm{p}$ value $<0.05)$. 
seasons. Calcium, iron and zinc concentrations showed a significant effect for the lines.

Grain yield showed greater variation amplitude in normal rainy season, from $354 \mathrm{~kg} \mathrm{ha}^{-1}$ (BRS Embaixador) to $1,966 \mathrm{~kg} \mathrm{ha}^{-1}$ (Light Red Kidney) (Table 2). The existence of genetic variability provides the identification of more productive lines for normal rainy season (Light Red Kidney, Red Kanner, Ouro Branco, Montcalm and IPR Garça), and for dry season (Cal-96, Branco Graúdo, IAC Galante e IAC Centauro).
A common accentuated reduction in bean grain yield can be observed during dry season in the south region of Brazil since grain filling to harvest period often coincides with the rainfall high intensity period, and small minimum temperature. However, Red Kanner, Chinook, BRS Radiante, and Cal-96 lines showed grain yield above $1,187 \mathrm{~kg} \mathrm{ha}^{-1}$ at the two growing seasons, and could be indicated for the normal rainy and dry seasons.

Mass of 100 grains varied from $26.33 \mathrm{~g}$ (BRS Embaixador, 2010 normal rainy season) to $55.60 \mathrm{~g}$ (WAF 75, 2011 dry season) (Table 2). In the normal rainy season, lines

Table 2. Mean of grain yield (yield), mass of 100 grains (mass), cooking time (cooking), and $\bar{Z}$ index of special grains bean lines obtained in 2010 normal rainy season, and 2011 dry season

\begin{tabular}{|c|c|c|c|c|c|c|c|c|c|c|c|c|c|c|c|c|}
\hline \multirow[t]{2}{*}{ Line } & \multicolumn{4}{|c|}{$\begin{array}{l}\text { Yield } \\
\left(\mathrm{kg} \mathrm{ha}^{-1}\right)\end{array}$} & \multicolumn{4}{|l|}{$\begin{array}{l}\text { Mass } \\
(\mathrm{g})\end{array}$} & \multicolumn{4}{|c|}{$\begin{array}{l}\text { Cooking } \\
\text { (minutes: seconds) }\end{array}$} & \multicolumn{4}{|c|}{$\overline{\mathbf{Z}}$ index } \\
\hline & 2010 & & 2011 & & 2010 & & 2011 & & 2010 & & 2011 & & 2010 & & 2011 & \\
\hline Red Kanner & 1,834 & $\mathrm{~A}$ & 1,224 & B & 38.39 & B & 43.47 & $\mathrm{D}$ & $20: 23$ & $\mathrm{~B}$ & $20: 15$ & $\mathrm{D}$ & 2.87 & B & 2.66 & B \\
\hline Ouro Branco & 1,718 & $\mathrm{~A}$ & 835 & $\mathrm{C}$ & 37.08 & $\mathrm{~B}$ & 52.80 & A & $18: 11$ & $\mathrm{C}$ & $20: 28$ & $\mathrm{D}$ & 3.11 & A & 3.08 & A \\
\hline Montcalm & 1,638 & $\mathrm{~A}$ & 1,124 & $\mathrm{~B}$ & 39.28 & $\mathrm{~B}$ & 48.53 & $\mathrm{~B}$ & $23: 13$ & A & $21: 50$ & $\mathrm{C}$ & 3.43 & A & 3.37 & A \\
\hline Chinook & 1,450 & B & 1,260 & $\mathrm{~B}$ & 40.82 & $\mathrm{~B}$ & 46.13 & $\mathrm{C}$ & $23: 20$ & A & $25: 34$ & $\mathrm{~B}$ & 3.28 & A & 3.08 & A \\
\hline Hooter & 1,402 & B & 711 & $\mathrm{C}$ & 45.36 & A & 54.27 & A & $24: 03$ & A & $23: 43$ & $\mathrm{C}$ & 3.58 & A & 3.63 & A \\
\hline BRS Radiante & 1,335 & B & 1,361 & B & 33.35 & $\mathrm{C}$ & 37.87 & $\mathrm{E}$ & $21: 23$ & $\mathrm{~B}$ & $26: 50$ & $\mathrm{~B}$ & 2.48 & B & 3.35 & A \\
\hline Cal-96 & 1,187 & B & 1,591 & A & 42.07 & B & 52.80 & A & $20: 23$ & $\mathrm{~B}$ & $36: 21$ & A & 3.25 & A & 4.13 & A \\
\hline Branco Graúdo & 1,032 & $\mathrm{C}$ & 1,556 & A & 33.18 & $\mathrm{C}$ & 46.40 & $\mathrm{C}$ & $22: 04$ & B & $32: 59$ & A & 2.47 & B & 3.55 & A \\
\hline IAC Galante & & & 1,717 & A & & & 28.13 & G & & & $14: 46$ & $\mathrm{E}$ & & & 3.04 & A \\
\hline IAC Centauro & & & 1,570 & $\mathrm{~A}$ & & & 26.00 & G & & & $16: 07$ & $\mathrm{E}$ & & & 3.00 & A \\
\hline Xamego & & & 1,384 & $\mathrm{~B}$ & & & 20.80 & $\mathrm{H}$ & & & $17: 20$ & $\mathrm{E}$ & & & 2.67 & B \\
\hline BRS MG Realce & & & 1,380 & $\mathrm{~B}$ & & & 34.80 & $\mathrm{~F}$ & & & $19: 52$ & $\mathrm{D}$ & & & 2.46 & B \\
\hline Rosinha G2 & & & 1,367 & $\mathrm{~B}$ & & & 23.33 & $\mathrm{H}$ & & & $16: 36$ & $\mathrm{E}$ & & & 2.50 & B \\
\hline Vermelho Graúdo & & & 1,333 & $\mathrm{~B}$ & & & 48.53 & $\mathrm{~B}$ & & & $24: 22$ & $\mathrm{C}$ & & & 3.15 & A \\
\hline Iraí & & & 1,222 & B & & & 36.93 & $\mathrm{E}$ & & & $21: 29$ & $\mathrm{C}$ & & & 3.00 & A \\
\hline IAC Harmonia & & & 1,216 & $\mathrm{~B}$ & & & 42.27 & $\mathrm{D}$ & & & $21: 50$ & $\mathrm{C}$ & & & 3.01 & A \\
\hline IAC Jabola & & & 1,052 & $\mathrm{C}$ & & & 40.53 & $\mathrm{D}$ & & & 19:11 & $\mathrm{D}$ & & & 2.58 & B \\
\hline OTG 07-01 & & & 1,024 & $\mathrm{C}$ & & & 53.73 & A & & & $23: 02$ & $\mathrm{C}$ & & & 3.16 & A \\
\hline $38 \mathrm{MON}$ p5-13 & & & 740 & $\mathrm{C}$ & & & 37.33 & $\mathrm{E}$ & & & $20: 38$ & $\mathrm{D}$ & & & 2.84 & B \\
\hline IAC Esperança & & & 721 & $\mathrm{C}$ & & & 37.20 & $\mathrm{E}$ & & & $23: 25$ & $\mathrm{C}$ & & & 2.61 & $\mathrm{~B}$ \\
\hline Mean & 1,245 & & 1,056 & & 37.38 & & 43.36 & & 20.76 & & $22: 59$ & & 2.93 & & 3.01 & \\
\hline $\mathrm{CV} \%$ & 15.67 & & 18.49 & & 7.11 & & 5.47 & & 8.31 & & 9.59 & & 16.95 & & 14.48 & \\
\hline
\end{tabular}

"Means not followed by the same letter in the column are different according to Scott-Knott test (value $\mathrm{p}=0.05$ ). 
with higher mass of 100 grains were Light Red Kidney and Hooter. In the dry season, Light Red Kidney, Ouro Branco, Hooter, Cal-96, WAF 75, BRS Executivo, OTG 07-01, OTG 07-03, and IAC Boreal lines were the top rank. Only Xamego and Rosinha G2 lines, of the Middle American gene pool, showed small grains, in accordance with the classification proposed by Blair et al. (2010). The other lines belong to the Andean gene pool, where 11 of

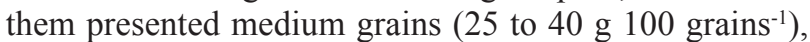

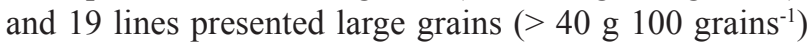
(Table 2). Large grains with white, red or cream tegument have high commercial value, and they often receive small offer in the international market.

Bean lines obtained from different growing seasons presented variable cooking time (Table 2 ). In the 2010 normal rainy season, lines with shorter cooking times were WAF 141 (15 min and 17s), and BRS Embaixador (14 min and 08s). On the other hand, in the 2011 dry season, lines with shorter cooking time were IAC Galante, IAC Centauro, Xamego and Rosinha G2. Considering that bean cultivars with cooking times lower than 30 minutes are more desirable for the consumers, since it means economy of money and energy (Rodrigues et al. 2005), only Cal-96, Branco Graúdo, and WAF 75 lines may presented restriction to consumption due to the longer cooking time needed for grain softness, if grains originate from crops of the dry season. Moreover, long cooking times are not recommended for they may cause structural alterations at cellular level, and consequently loss of nutrients (Wassimi et al. 1988).

No significant difference ( $\mathrm{p}$ value $>0.05$ ) was observed for potassium (mean of $15.30 \mathrm{~g} \mathrm{~kg}^{-1}$ of dry matter - DM) and copper concentrations (mean of $8.94 \mathrm{mg} \mathrm{kg}^{-1}$ of DM) among special grains bean lines (Tables 1 and 3 ). However, Mesquita et al. (2007) evaluated copper and potassium concentrations in 21 bean lines with varied tegument colors, and observed genetic variability for these minerals. In this case, differences observed can be justified by a genetic variability among lines of different gene pool, by the type of soil, and by differences in meteorological conditions.

Bean lines were classified, according to Skott-Knott test ( $p$ value $=0.05$ ), in two groups for calcium concentration: low (0.88 to $1.29 \mathrm{~g} \mathrm{~kg}^{-1}$ of dry matter - DM), and high (1.38 to $1.80 \mathrm{~g} \mathrm{~kg}^{-1}$ of DM) (Table 3). In previous studies, identical amplitude was observed for calcium concentration in Middle American bean lines, of carioca and black teguments, grown in Brazil (Jost et al. 2009), and in 29 Andean and Middle American bean lines, of different tegument colors, cultivated in Brazil, the United States and Colombia (Akond et al. 2011). Nevertheless, it was possible to find bean lines with calcium values up to $3.15 \mathrm{~g} \mathrm{~kg}^{-1}$ of DM in the Bank of Germplasm of the International Center for
Tropical Agriculture (Beebe et al. 2000).

Through Scott-Knott test it was possible to develop stratifications for the three groups of lines concerning iron concentration in grains: moderate $\left(57.15\right.$ to $90.95 \mathrm{mg} \mathrm{kg}^{-1}$ of DM), high (95.05 to $108.20 \mathrm{mg} \mathrm{kg}^{-1}$ of DM) and very high (129.50 to $159 \mathrm{mg} \mathrm{kg}^{-1}$ of DM). This classification was similar to the one presented by Tryphone and Nchimbi-Msolla (2010) for 90 bean lines evaluated in Tanzania: low iron (23.6 to $42.0 \mathrm{mg} \mathrm{kg}^{-1}$ of DM), moderate iron (43.0 to 59.6 $\mathrm{mg} \mathrm{kg}{ }^{-1}$ of DM) and high iron (60.4 to $105.5 \mathrm{mg} \mathrm{kg}^{-1}$ of DM).

Special grains bean lines with very high iron concentration (Ouro Branco, Hooter, 38 MON p5-13, BRS Radiate and IAC Harmonia) showed higher values than the observed in bean accesses stored in one of the largest worldwide collections of wild and cultivated bean species (Beebe et al 2000). Such high values for iron in bean grains had already been described in bean cultivars grown in many countries (Welch et al. 2000), and in crioule bean cultivars cultivated in Brazil (Pereira et al. 2011). Moreover, 10 lines presented high iron concentration in grains $\left(95.05\right.$ to $108.20 \mathrm{mg} \mathrm{kg}^{-1}$ of DM): IAC Centauro, IAC Galante, WAF 141, Xamego, BRS Embaixador, Montcalm, IAC Boreal, OTG 07-09, Iraí and Chinook. Therefore, $46.87 \%$ of the special grains bean lines evaluated presented high or very high concentrations of iron, and thus, they are indicated for biofortification programs. The use of these lines in diet can contributes to prevent anemia, which is a serious problem of public health in the world.

Zinc concentration varied from 21.85 (BRS MG Realce) to $34.85 \mathrm{mg} \mathrm{kg}^{-1}$ of DM (IAC Centauro), and although a significant difference was identified by the $F$ test (p value $<0.05$ ) for the lines, the application of Scott-Knott test did not lead to stratification between treatments for the same level of significance (Table 3). Similar zinc concentration was observed in bean lines evaluated in the United States (Moraghan and Grafton 2001), in Colombia (Cichy et al. 2009) and in Ruanda (Beebe et al. 2000). However, greater zinc concentration was observed in bean lines of the Middle American gene pool cultivated in Brazil (Mesquita et al. 2007, Rosa et al. 2010). Considering that $49 \%$ of the world population present a risk for developing zinc deficiency symptoms due to a low ingestion of this mineral in their meals (Brown et al. 2001), the increase of zinc concentrations by biofortification may contribute for preventing malnutrition symptoms. There is an expectation that it is possible to increase zinc concentration in bean grains in $50 \%$ by genetic improvement, based on the genetic variability available in accesses stored in CIAT (Beebe et al. 2000).

IAC Centauro, IAC Galante, WAF 141, Xamego, Ouro Branco, BRS Embaixador, Montcalm, IAC Boreal and Hooter lines presented high calcium $\left(>1.42 \mathrm{~g} \mathrm{~kg}^{-1} \mathrm{DM}\right)$, 
iron $\left(>95.05 \mathrm{mg} \mathrm{kg}^{-1} \mathrm{DM}\right)$ and zinc $\left(>29.05 \mathrm{mg} \mathrm{kg}^{-1} \mathrm{DM}\right)$ concentrations in grains, and therefore, are recommended for biofortification programs. If grains of these lines were used as part of a balanced diet, they could contribute to minimize the lack of nutrition that causes risk to the health, such as deficiencies of calcium, iron or zinc.

However, WAF 141, BRS Embaixador e IAC Boreal lines showed low grain yield (Table 2). Therefore, regarding high nutritional value, reduced cooking time and high grain yield, IAC Centauro, IAC Galante, Xamego, Ouro Branco, Montcalm, and Hooter lines are indicated for the conditions evaluated in the present study.

$\overline{\mathrm{Z}}$ index obtained for all characters with the graphic representation for the lines facilitates the selection of inbred lines with higher $\bar{Z}$ indexes for the most of the characters. Therefore, Figure 1 represents nine lines with the highest $\bar{Z}$ indexes mean for all the characters. Cal-96 line calls attention for its highest $\bar{Z}$ indexes for grain yield, mass of 100 grains, calcium, zinc and copper concentrations. However, cooking time was long (not recommended), and potassium concentration was low, which can be an advantage for patients with compromised kidney functions. For this case, Louis and Dolan (1970) have recommended potassium restrictions in dietary programs. Hooter line, on the other hand, displayed a differentiated mass of 100 grains, potassium, iron and copper concentrations. Controlled crossing between Cal-96 and Hooter is recommended, and selection

Table 3. Mean* of potassium, calcium, iron, zinc and copper concentrations of special grains bean lines obtained in normal rainy and dry seasons

\begin{tabular}{|c|c|c|c|c|c|c|c|c|}
\hline \multirow[t]{2}{*}{ Line } & Potassium & \multicolumn{2}{|c|}{ Calcium } & Iron & \multicolumn{3}{|c|}{ Zinc } & Copper \\
\hline & \multicolumn{3}{|c|}{$\ldots \mathrm{g} \mathrm{kg}^{-1}$ of dry matter $\ldots$} & \multicolumn{5}{|c|}{$\ldots \mathrm{mg} \mathrm{kg}^{-1}$ of dry matter... } \\
\hline Cal-96 & $14.25^{\mathrm{ns}}$ & 1.80 & A & 83.30 & $\mathrm{C}$ & 30.20 & A & $11.00^{\mathrm{ns}}$ \\
\hline IAC Centauro & 14.65 & 1.77 & A & 97.60 & B & 34.85 & A & 10.35 \\
\hline IAC Galante & 14.00 & 1.72 & A & 102.40 & B & 33.95 & A & 10.18 \\
\hline WAF 141 & 18.00 & 1.66 & A & 95.05 & B & 29.60 & A & 9.36 \\
\hline Xamego & 16.50 & 1.64 & A & 97.80 & B & 30.40 & A & 8.67 \\
\hline Rosinha G2 & 12.25 & 1.63 & A & 75.85 & $\mathrm{C}$ & 28.60 & A & 7.27 \\
\hline Ouro Branco & 14.62 & 1.62 & A & 133.80 & A & 29.65 & A & 10.92 \\
\hline BRS Embaixador & 19.65 & 1.53 & A & 98.85 & B & 29.45 & A & 9.65 \\
\hline Montcalm & 15.83 & 1.44 & A & 107.23 & B & 37.70 & A & 9.95 \\
\hline IAC Boreal & 12.95 & 1.43 & A & 106.50 & $\mathrm{~B}$ & 38.95 & A & 10.95 \\
\hline Hooter & 20.77 & 1.42 & A & 159.00 & A & 29.05 & A & 10.09 \\
\hline IPR Garça & 17.06 & 1.39 & A & 81.65 & $\mathrm{C}$ & 29.50 & A & 8.16 \\
\hline Branco Graúdo & 13.30 & 1.38 & A & 65.10 & $\mathrm{C}$ & 27.65 & A & 7.09 \\
\hline WAF 75 & 16.23 & 1.38 & A & 58.11 & $\mathrm{C}$ & 27.26 & A & 8.15 \\
\hline IAC Esperança & 12.75 & 1.29 & $\mathrm{~B}$ & 74.95 & $\mathrm{C}$ & 26.25 & A & 8.41 \\
\hline OTG 07-09 & 14.75 & 1.27 & $\mathrm{~B}$ & 104.10 & $\mathrm{~B}$ & 31.35 & A & 9.14 \\
\hline IAC Jabola & 13.75 & 1.21 & $\mathrm{~B}$ & 70.45 & $\mathrm{C}$ & 26.40 & A & 6.83 \\
\hline Iraí & 14.25 & 1.19 & $\mathrm{~B}$ & 108.20 & B & 30.60 & A & 10.15 \\
\hline Dark Red Kidney & 19.95 & 1.16 & $\mathrm{~B}$ & 87.95 & $\mathrm{C}$ & 28.10 & A & 9.12 \\
\hline 38 MON p5-13 & 12.90 & 1.16 & B & 138.00 & A & 32.95 & A & 10.15 \\
\hline BRS Radiante & 14.85 & 1.14 & $\mathrm{~B}$ & 139.50 & A & 28.20 & A & 10.77 \\
\hline OTC 07-03 & 15.70 & 1.11 & B & 89.40 & $\mathrm{C}$ & 27.10 & A & 8.02 \\
\hline Light Red Kidney & 11.93 & 1.10 & $\mathrm{~B}$ & 86.85 & $\mathrm{C}$ & 24.75 & A & 8.66 \\
\hline Vermelho Graúdo & 15.50 & 1.09 & B & 73.40 & $\mathrm{C}$ & 29.75 & A & 8.15 \\
\hline IAC Harmonia & 14.05 & 1.08 & B & 129.50 & A & 26.50 & A & 6.85 \\
\hline Chinook & 14.17 & 1.04 & $\mathrm{~B}$ & 99.20 & $\mathrm{~B}$ & 27.15 & A & 8.55 \\
\hline TB 02-24 & 14.25 & 1.03 & $\mathrm{~B}$ & 65.70 & $\mathrm{C}$ & 22.25 & A & 6.76 \\
\hline Cranberry & 12.75 & 0.98 & $\mathrm{~B}$ & 64.05 & $\mathrm{C}$ & 24.00 & A & 5.81 \\
\hline Red Kanner & 14.40 & 0.96 & $\mathrm{~B}$ & 69.05 & $\mathrm{C}$ & 22.15 & A & 7.82 \\
\hline OTG 07-01 & 17.40 & 0.93 & $\mathrm{~B}$ & 90.95 & $\mathrm{C}$ & 27.00 & A & 8.52 \\
\hline BRS MG Realce & 12.65 & 0.92 & $\mathrm{~B}$ & 57.15 & $\mathrm{C}$ & 21.85 & A & 7.37 \\
\hline BRS Executivo & 16.32 & 0.88 & $\mathrm{~B}$ & 57.40 & $\mathrm{C}$ & 24.07 & A & 9.04 \\
\hline Mean & 15.30 & 1.38 & & 89.72 & & 29.22 & & 8.94 \\
\hline C.V.\% & 22.72 & 16.63 & & 20.58 & & 14.30 & & 21.46 \\
\hline
\end{tabular}

"Mean not followed by the same letter in the column are different according to Scott-Knott test (value $\mathrm{p}=0.05)$; ns $=$ not significant. 
of recombinants obtained may result in the development of new bean cultivars with higher grain yield and nutritional qualities characters.

IAC Boreal line showed higher $\bar{Z}$ indexes for most of

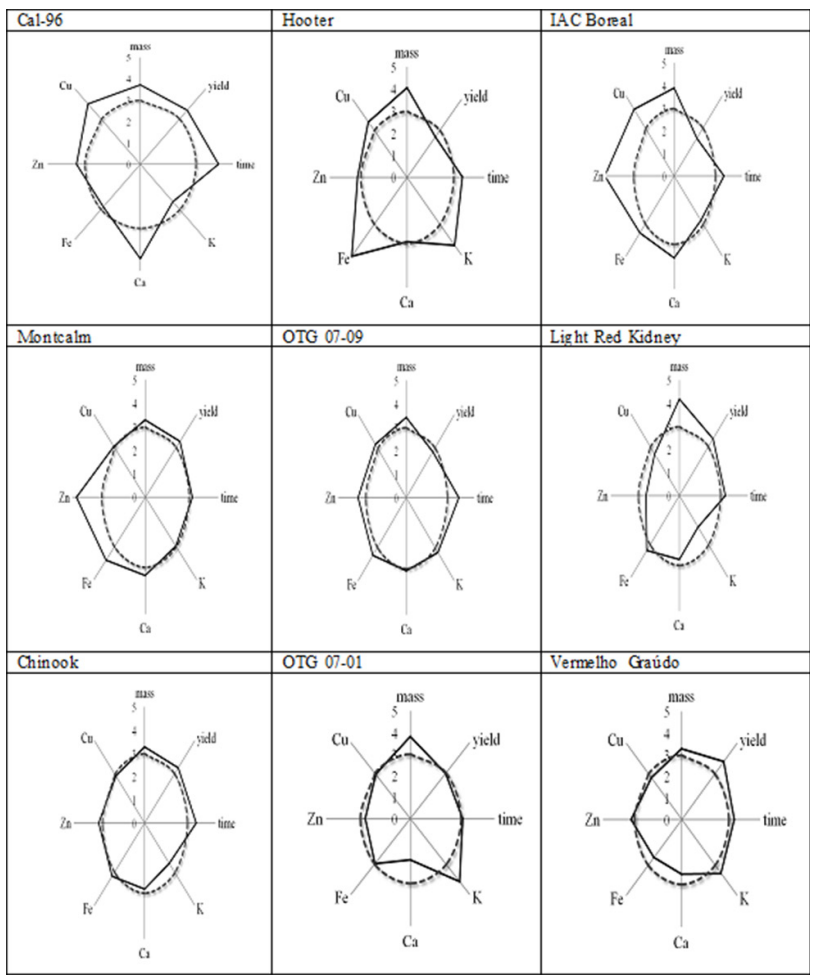

Legend: $=\bar{Z}$ index; $-\cdots--=$ mean $=3$.

Figure 1. Graphic representation of $\bar{Z}$ indexes for grain yield (yield), mass of 100 grains (mass), cooking time (time), potassium (K), calcium $(\mathrm{Ca})$, iron $(\mathrm{Fe})$, zinc $(\mathrm{Zn})$, and copper $(\mathrm{Cu})$ concentrations in grains of nine special grains bean lines which presented the highest $\bar{Z}$ index mean for all characters. the minerals (calcium, iron, zinc and copper). Similarly, Safira line showed higher $\bar{Z}$ indexes for minerals and protein of 100 lines of the Bean Germplasm Bank of the Federal University of Lavras. In the present study, OTG 07-09 line called attention for its high potassium, iron, zinc and copper $\bar{Z}$ indexes. IAC Boreal and OTG 07-09 lines presented higher mass of 100 grains and were more complete for the evaluated minerals, although grain yield was low (Table 2). Therefore, difficulties will permeate the selection of special grains bean lines with high grain yield, high mass of 100 grains, reduced cooking time and higher mineral concentrations. The strategy for identifying special grains bean lines, when most of the characters are combined, is a situation to be considered by bean breeding programs.

\section{CONCLUSIONS}

Special grains bean lines show genetic variability for grain yield, mass of 100 grains, cooking time, and calcium, iron and zinc concentrations in grains. IAC Centauro, IAC Galante, Xamego, Ouro Branco, Montcalm, and Hooter lines have high nutritional value, reduced cooking time and high grain yield, and their use is recommended for diets. Cal-96 line presents higher $\bar{Z}$ indexes for grain yield, and most of the minerals, in special grain bean line, and its use is recommended by crosses for the development of superior lines.

\section{ACKNOWLEDGEMENTS}

We thank the National Council of Technological and Scientific Development (CNPq) for the financial aid and scholarships granted. To Embrapa Rice and Beans, and the Agronomy Institute of Campinas, for availability of bean seeds. The authors would also like to thank Fabiano Kauer (Shimadzu) for technical support in ICP-OES analyses.

\section{Avaliação de linhagens de feijão de grãos especiais para produtividade, tempo de cozimento e concentração de minerais}

Resumo - A variabilidade genética de 32 linhagens de feijão de grãos especiais foi investigada para produtividade de grãos, massa de 100 grãos, tempo de cozimento e concentração de minerais nos grãos, e o índice $\bar{Z}$ foi usado para a seleção de linhagens com superioridade para a maioria dos caracteres. As linhagens IAC Centauro, IAC Galante, Xamego, Ouro Branco, Montcalm e Hooter apresentaram alta produtividade de grãos, reduzido tempo de cozimento (menor do que 24 min) e alta concentração de potássio (>14 $\mathrm{g} \mathrm{kg}^{-1}$ de matéria seca [MS]), cálcio (>1,42 $\left.\mathrm{g} \mathrm{kg}^{-1} \mathrm{MS}\right)$, ferro (>97,60 $\left.\mathrm{mg} \mathrm{kg}^{-1} \mathrm{MS}\right)$, zinco (>29,05 mg kg-1 MS) e cobre (>8,67 $\mathrm{mg} \mathrm{kg}^{-1}$ $M S)$, e seu uso na dieta é recomendado. A linhagem Cal-96 tem maior indice $\overline{\mathrm{Z}}$ para produtividade de grãos e para a maioria dos minerais, e seu uso é recomendado para cruzamentos para o desenvolvimento de linhagens superiores.

Palavras-chave: Phaseolus vulgaris, qualidade nutricional, variabilidade genética, índice $\overline{\mathrm{Z}}$.

\section{REFERENCES}

Akond ASMGM, Crawford H, Berthold J, Talukder ZI and Hossain

$\mathrm{K}$ (2011) Minerals (Zn, Fe, Ca and Mg) and antinutrient (phytic acid) constituents in common bean. American Journal of Food Technology 6: 35-243.
Beebe S, Gonzalez V and Rengifo J (2000) Research on trace minerals in the common bean. Food and Nutrition Bulletin 21: 387-391.

Blair MW, González LF, Kimani PM and Butare L (2010) Genetic diversity, inter-gene pool introgression and nutritional quality of common beans (Phaseolus vulgaris L.) from Central Africa. Theorical Applied 
ND Ribeiro et al.

Genetic 121: 237-248.

Brown KH, Wuehler SE and Peerson JM (2001) The importance of zinc in human nutrition and estimation of the global prevalence of zinc deficiency. Food and Nutrition Bulletin 22: 113-125.

Cichy KA, Caldas GV, Snapp SS and Blair MW (2009) QTL analysis of seed iron, zinc, and phosphorus levels in a Andean bean population. Crop Science 49: 1742-1750.

Cruz CD (2006) Programa Genes: estatística experimental e matrizes. Editora UFV, Viçosa, 382p.

FAO (2011) Food and Agriculture Organization of the United Nations. FAOSTAT. Available at $<\mathrm{http}$ ://www.faostat.fao.org $>$ Assessed on March 24, 2011.

Islam FMA, Basford KE, Jara C, Redden RJ and Beebe S (2002) Seed composition and disease resistance differences among gene pools in cultivated common bean. Genetic Resources and Crop Evolution 49: 285-293.

Jost E, Ribeiro ND, Maziero SM, Cerutti T and Rosa DP (2009) Efeitos gênicos do teor de cálcio em grãos de feijão. Ciência Rural 39: 31-37.

Louis CJ and Dolan EM (1970) Removal of potassium in potatoes by leaching. Journal of the American Dietetic Association 57: 42-43.

Mendes FF, Ramalho MAP and Abreu AFB (2009) Índice de seleção para escolha de populações segregantes de feijoeiro-comum. Pesquisa Agropecuária Brasileira 44: 1312-1318.

Mesquita FR, Corrêa AD, Abreu CMP, Lima, RAZ and Abreu AFB (2007) Linhagens de feijão (Phaseolus vulgaris L.): composição química e digestibilidade protéica. Ciência e Agrotecnologia 31: 1114-1121.

Moraghan JT and Grafton K (2001) Genetic diversity and mineral composition of common bean seed. Journal of the Science of Food and Agriculture 81: 404-408.

Pereira T, Coelho, CMM, Santos JCP, Bogo A and Miquelluti DJ (2011) Diversidade no teor de nutrientes em grãos de feijão crioulo no Estado de Santa Catarina. Acta Scientiarum Agronomy 33: 477-485.

Ribeiro ND, Cargnelutti Filho A, Poersch NL and Rosa SS (2007)
Padronização de metodologia para avaliação do tempo de cozimento dos grãos de feijão. Bragantia 66: 335-348.

Ribeiro ND, Maziero SM, Prigol M, Nogueira CW, Rosa DP and Possobom MTDF (2012) Mineral concentrations in the embryo and seed coat of common bean cultivars. Journal of Food Composition and Analysis doi:10.1016/j.jfca.2012.03.003 (in press).

Rodrigues JA, Ribeiro ND, Londero PMG, Cargnelutti Filho A and Garcia DC (2005) Correlação entre absorção de água e tempo de cozimento de cultivares de feijão. Ciência Rural 35: 209-214.

Rosa SS, Ribeiro ND, Jost E, Reiniger LRS, Rosa DP and Cerutti T (2010) Potential for increasing the zinc content in common bean using genetic improvement. Euphytica 175: 207-213.

Silva CA, Abreu AFB, Ramalho MAP and Maia LGS (2012) Chemical composition as related to seed color of common bean. Crop Breeding and Applied Biotechnology 12: 132-137.

Singh SP, Gepts P and Debouch DG (1991) Races of common bean (Phaseolus vulgaris, Fabaceae). Economic Botany 45: 379-396.

Steel RGD, Torrie JH and Dickey DA (1997) Principles and procedures of statistics: a biometrical approach. $3^{\text {rd }}$ ed., McGraw Hill Book, New York, 666p.

Talukder ZI, Anderson E, Miklas PN, Blair MW, Osorno J, Dilawari M and Hossain KG (2010) Genetic diversity and selection of genotypes to enhance $\mathrm{Zn}$ and Fe content in common bean. Canadian Journal of Plant Science 90: 49-60.

Tryphone GM and Nchimbi-Msolla S (2010) Diversity of common bean (Phaseolus vulgaris L.) genotypes in iron and zinc contents under screenhouse conditions. African Jounal of Agricultural Research 5: $738-747$.

Wassimi NN, Hosfield GL and Uebersax MA (1988) Combining ability of tannin content and protein characteristics of raw and cooked dry beans. Crop Science 28: 452-458.

Welch RM, House WA, Beebe S and Cheng Z (2000) Genetic selection for enhanced bioavailable levels of iron in bean (Phaseolus vulgaris L.) seeds. Journal of Agricultural and Food Chemistry 48: 3576-3580. 